\title{
Modelling silvicultural alternatives for conifer regeneration in boreal mixedwood stands (aspen/white spruce/balsam fir)
}

\author{
by D.F. Greene ${ }^{1}$, D.D. Kneeshaw ${ }^{2,6}$, C. Messier ${ }^{3}$, V. Lieffers ${ }^{4}$, D. Cormier ${ }^{5}$, R. Doucet ${ }^{6}$, \\ K.D. Coates ${ }^{7}$, A. Groot ${ }^{8}$, G. Grover ${ }^{9}$ and C. Calogeropoulos ${ }^{10}$
}

We model and compare the biological and financial constraints of four prescriptions that serve as alternatives to conventional clearcutting followed by planting in eastern and western boreal mixedwood stands. These alternative prescriptions for full or partial conifer stocking are (1) reliance on advance regeneration with or without augmentation by fill-planting; (2) understory scarification during a mast year; (3) direct seeding either aerially or with a scarifier-seeder; and (4) underplanting. Our main conclusions concerning the biological constraints are that (1) advance regeneration, mainly of balsam fir in the east and white spruce in the west, requires $>26000$ and $>4000$ trees/ha (because of different distributions), respectively, to achieve full conifer stocking; (2) reliance on a mast year requires at least $6 \mathrm{~m}^{2} /$ ha of mature conifer basal area, but much less if some advance regeneration is present or only moderate stocking is desired; (3) aerial seeding with $35 \%$ scarification requires about a half-million seeds/ha to achieve full conifer stocking, while a scarifier-seeder would require only a third of this application rate; and (4) underplanting is constrained to aspen stands with $>25 \%$ incident light at planting height. In all cases, alternative prescriptions become more feasible if only moderate or minimal stocking is the silvicultural objective. A costing exercise for the four prescriptions in comparison with a clearcut followed by planting shows that reliance on advance regeneration or understory planting are the cheapest alternatives to achieve full or partial conifer stocking. With the exception of full conifer stocking in situations where there is little advance regeneration (and where herbicides can be used), conventional plantations are never the cheapest approach. In such cases, fill planting and use of a scarifier-seeder become viable options. Aerial seeding and reliance on a mast year are the most expensive of the alternatives. We conclude, tentatively, that there is enough conifer basal area in most of the eastern boreal mixedwood of Canada to allow for the use of either or both a mast year and advance regeneration to achieve full or partial conifer stocking. By contrast, in the west conifer basal area will seldom be sufficient for natural seeding, and the density of advance regeneration is likewise often too low. Finally, because of light constraints, understory planting appears to have a much wider applicability in the west than in the east.

Key words: boreal mixedwood silviculture, white spruce, balsam fir, understory scarification, understory planting, advance regeneration, direct seeding

Nous avons modélisé et comparé les contraintes biologiques et financières de quatre prescriptions qui ont servi d'alternatives à la coupe à blanc conventionnelle suivie de plantation dans des peuplements boréaux mélangés de l'Est et de l'Ouest. Ces prescriptions alternatives pour une densité relative complète ou partielle en résineux sont (1) tenir compte de la régénération pré-établie avec ou sans addition par regarnissage; (2) scarifiage du sous-étage au cours d'une année semencière; (3) ensemencement direct soit par voie aérienne ou au moyen d'un scarificateur-ensemenceur; et (4) plantation en sous-étage. Nos principales conclusions au sujet des contraintes biologiques sont que (1) la régénération pré-établie, surtout dans le cas du sapin baumier dans l'Est et de l'épinette blanche dans l'Ouest doit atteindre >26000 et > 4000 arbres/ha (à cause de distributions différentes) respectivement, pour atteindre une densité relative complète en résineux; (2) pour compter sur une année semencière, il faut au moins $6 \mathrm{~m}^{2} / \mathrm{ha}$ de surface terrière de conifères à maturité, mais beaucoup moins s'il y a un peu de régénération pré-établie ou qu'une densité relative modérée est désirée; (3) l'ensemencement aérien avec un scarifiage de $35 \%$ nécessite près d'un demi million de semences par hectare pour atteindre une densité relative complète en résineux, tandis qu'un scarificateur-ensemenceur aurait besoin de seulement un tiers de cette quantité; et (4) la plantation en sous-étage se limite aux peupleraies ayant $>25 \%$ de lumière incidente à hauteur de plantation. Dans tous ces cas, les prescriptions alternatives deviennent plus faciles si seulement une densité relative modérée ou minimale a été retenue en tant qu'objectif sylvicole. Une évaluation des coûts pour les quatre prescriptions en comparaison avec la coupe à blanc suivie d'une plantation indique que se fier à la régénération pré-établie ou la plantation en sous-étage constituent les alternatives les moins coûteuses pour atteindre une densité relative complète ou partielle en résineux. À l'exception d'une densité relative complète en résineux dans des situations où il y a peu de régénération pré-établie (et où les phytocides peuvent être utilisés), les plantations conventionnelles ne constituent jamais l'approche la moins coûteuse. Dans de tells cas, le regarnissage et l'utilisation d'un scarificateur-ensemenceur deviennent des options viables. L'ensemencement aérien et compter sur une année semencière sont les plus dispendieuses de ces alternatives. Nous concluons, de façon tentative, qu'il y a suffisamment de surface terrière en résineux dans la plupart des peuplements mélangés boréaux de l'Est du Canada pour permettre l'utilisation soit de l'année semencière, soit de la régénération pré-établie ou des deux pour atteindre une densité relative complète ou partielle en résineux. Par contre, dans l'Ouest, la surface terrière en résineux sera rarement suffisante pour permettre un ensemencement naturel, et la densité de la régénération pré-établie est bien souvent trop faible. Finalement, à cause des contraintes de luminosité, la plantation en sous-étage semble être beaucoup plus applicable dans l'Ouest que dans l'Est.

Mots-clés: sylviculture des peuplements mélangés boréaux, épinette blanche, sapin baumier, scarifiage du sous-étage, régénération pré-établie, ensemencement direct

${ }^{1}$ Groupe de recherche en écologie forestière intreuniversitaire (GREFi), Department of Geography, Concordia University, 1455, boul. de Maisonneuve West, Montréal (Québec) H3G 1M8. E-mail: greene@alcor.concordia.ca ${ }^{2}$ GREFi, Université du Québec à Montréal, C.P. 8888, Succursale Centre-Ville, Montréal (Québec) H3C 3P8. E-mail: kneeshaw.daniel@uqam.ca

${ }^{3}$ GREFi, Université du Québec à Montréal, C.P. 8888, Succursale Centre-Ville, Montréal (Québec) H3C 3P8. E-mail: messier.christian@uqam.ca ${ }^{4}$ Department of Renewable Resources (ESB 4-42), University of Alberta, Edmonton, Alberta T6G 2E3. E-mail: vic.lieffers@ualberta.ca

${ }^{5}$ Forest Research Institute of Canada, 580 Boul. Sainte-Jean, Pointe-Claire, Quebec H9R 3J9. E-mail: denis-c@mtl.feric.ca
${ }^{6}$ Direction de la recherche forestière, Ministère des Ressources naturelles, 2700, rue Einstein, Sainte-Foy (Québec) G1P 3W8. E-mail: rene.doucet@ videotron.ca ${ }^{7}$ British Columbia Forest Service, Research Section, Bag 5000, Smithers, BC V0J 2N0. E-mail: Dave.Coates@gems7.gov.bc.ca

${ }^{8}$ Great Lakes Forestry Centre, Canadian Forest Service, 1219 Queen St. E., Sault Ste. Marie, Ontario P6A 5M7. E-mail: agroot@nrcan.gc.ca

${ }^{9}$ Alberta-Pacific Forest Industries Inc., Box 8000, Boyle, Alberta T0A 2C0. E-mail: groverbr@alpac.ca

${ }^{10} \mathrm{GREFi}$, Department of Biology, Concordia University, 1455, boul. de Maisonneuve West, Montréal (Québec) H3G 1M8. E-mail: c_calog@alcor.concordia.ca 


\section{Introduction}

In the last four decades, there has been a rapid evolution in mixedwood management. Early diameter limit cutting, where the most commercially valuable species and individuals were cut as needed, was coupled with a laissez faire attitude that resulted in variable stand establishment success. A few decades ago, this approach was replaced by clearcutting and even-age, single species management (Lieffers et al. 1996a). Given provincial regeneration standards, planting has been used to ensure stocking of conifers. Much more recently, some flexibility was introduced as mixedwoods were allowed to be regenerated as either pure coniferous or pure deciduous stands, depending on the pre-harvest proportion of the species.

With the recent developments in ecosystem management (Rowe 1992), there is an increasing interest in using management systems that more closely mimic natural stand dynamics. This interest can be driven by financial as well as environmental concerns to maintain the mixed species composition. Further, this recognition has begun to lead to changes in management objectives. For example, a number of provinces have recently produced new regeneration standards that attempt to replicate the proportion of conifers in the stand prior to harvest. That is, we are now beginning to see a gradient of stocking criteria that depends on the pre-harvest composition. This is an interesting development because, as we will see, the capacity for successful natural recruitment is greatly affected by the stocking standard.

Mixedwood boreal forests are found on mesic sites from Alaska to the Maritimes, and are composed of white spruce (Picea glauca (Moench) Voss)), balsam fir (Abies balsamea), trembling aspen (Populus tremuloides Michx.) and other minor species. White spruce and aspen are the main constituents of mixedwood stands in western Canada (Lieffers et al. 1996a). In the east, balsam fir is much more common than white spruce (Kneeshaw and Bergeron 1998) although there is interest in increasing the abundance of white spruce in the east via silvicultural manipulations.

The first goal of this paper is to quantify the biotic limitations on white spruce and balsam fir regeneration alternatives for the mixedwood forests of Canada. An emphasis is made on prescriptions that keep costs low. While these alternatives may fulfil other objectives, such as maintaining a natural composition and structure, and maintaining biological legacies (i.e., standing live and dead trees), these are considered here to be serendipitous consequences. Every prescription discussed here (or variants of them) has been tested, at least on a trial basis, a number of times somewhere in Canada. It is hoped that the modelling approach here can replace the present ruleof-thumb basis for evaluating silvicultural alternatives and illustrate current gaps in knowledge.

Our second objective is to show how the most cost-effective prescription available can depend on the stocking objective. As the full stocking criterion is relaxed, some prescriptions are favoured relative to the conventional clearcut/plantation.

Our final goal is not merely to quantify costs but to deal with a central concern of forest managers: reliability. For simplicity, we have chosen $84 \%$ (one standard deviation beyond the mean) as our standard of reliability for each estimate in a model. But the coupling of equations within a model will lead to a propagation of error. Now, aside from underplanting (for which we have no reliability estimates), our models for ade- quate stocking via advance regeneration or post-harvest seedlings each rely on no more than two estimates. Thus, the error propagation will lead to a prescription reliability estimate of $71 \%\left(0.84^{2}=0.71\right)$. (That is, the prescription is expected to meet the stocking criteria in 71 of every 100 blocks.) We would have preferred to use estimates of the reliability of the clearcut/plantation option but, surprisingly, we could find no summary evaluation of current success rates. In any case, the approach we advance here is flexible; a forester can increase the reliability by demanding a higher standard for each of the life history parameter estimates in the model.

We warn the reader that aspen regeneration strategies for mixedwood stands are not discussed here, but see Peterson and Peterson (1992) and Lieffers et al. (1996a) for a discussion. Indeed, in this paper aspen is seen merely as a potential competitor of the conifer regeneration. Further, we focus solely on the regeneration of white spruce and balsam fir, ignoring other species such as paper birch (Betula papyrifera).

As a final warning, the reader is reminded that the success of this modelling effort is utterly dependent on the empirical literature for parameterization. We found a number of gaps in the literature as we attempted to assign values to particular parameters. As we develop the models below, we will point out these gaps, discuss how we arrive at parameter values, and proceed with the modelling. Nonetheless, because of these problems our results must be regarded as tentative. Indeed, the primary merit of the present exercise may be that it makes clear where the gaps in our knowledge lie, and serves therefore as a guide to subsequent research.

\section{Alternative prescriptions}

Four alternatives to the conventional clearcut/plantation are presented below.

\section{Prescription 1: Reliance on advance regeneration}

This prescription has recently become common in parts of eastern Canada (Doucet 1992), and is likely to increase in importance. For this prescription we develop a simple model that incorporates pre-harvest advance regeneration density, expected mortality during the harvesting operation, and the relationship between stocking and density, to arrive at the pre-harvest density required to obtain adequate stocking. For this prescription, white spruce and balsam fir are treated as if they have similar intra-harvest and post-harvest mortality. Fill planting can be used to augment stocking where advance regeneration is insufficient to meet a given stocking standard. The reader is warned that we view fill planting as a gradient that ranges from essentially no intervention (i.e., advance regeneration is nearly enough by itself to meet the standard) to a conventional plantation (there is no advance regeneration at all).

\section{Prescription 2: Natural regeneration from seed following understory scarification in a mast year}

While this prescription has rarely been employed, trials during mast years (Lees 1963, 1970; Desjardins 1988; Stewart et al. 2000) show that it can be effective. Our model evaluates the relationship between seed production, juvenile survivorship, and scarification intensity.

\section{Prescription 3: Direct seeding following scarification}

This prescription has been tried many times with white spruce (our modelling effort will ignore fir) and trial records 
indicate poor reliability (Waldron 1974). We model the relationship between the scarification intensity and the sowing rate required for spruce stocking. As a variant on aerial seeding, we examine direct seeding by a scarifier-seeder machine.

\section{Prescription 4: Understory planting prior to logging}

This prescription is currently being tested in western Canada (Stewart et al. 2000; B. Grover, pers. comm.). It has the advantage of establishing the conifers well before the often-severe competition that can develop after canopy tree removal on mixedwood sites across Canada (Lieffers et al. 1993b, Groot 1999). We ignore fir, limiting the prescription to the more valuable white spruce.

\section{Review of biotic constraints and model formulation}

The basic equations governing the success rate of recruitment by seed are provided here as a preamble to the development of the prescription models.

\section{Seed production}

The mean annual number of filled seeds $/ \mathrm{m}^{2}\left(\mathrm{Q}_{\mathrm{D}}\right)$ produced by a single stand of spruce or fir is directly proportional to its basal area $\left(B_{D)}\right.$ expressed in $\mathrm{m}^{2} / \mathrm{m}^{2}$, and inversely proportional to mean seed size $\left(\mathrm{m}_{\mathrm{s}}\right.$, expressed in grams (Greene et al. 1999)):

[1] $\mathrm{Q}_{\mathrm{D}}=3067 \mathrm{~m}_{\mathrm{S}}^{-0.58} \mathrm{~B}_{\mathrm{D}}$

This relationship explains $82 \%$ of the variance for a wide range of conifer and hardwood species. Now, temporal variation around the mean value expressed in equation (1) is of course enormous. Indeed, temporal crop records are so strongly rightskewed that the mean crop would itself be regarded as a mast year. Clearly, it is worthwhile to avoid this uncertainty and thus our Prescription \#2 assumes that a mast year is known to be occurring.

We often lump spruce and fir together as a single conifer component in our models. This will have no effect on our expression of the temporal variation in seed production, as these two species appear to respond to meteorological cues for masting in an almost identical manner. We took the two six-year studies (there was no temporal overlap) of Randall (1974) and Raymond (1998) and regressed the natural logs of fir seed production on spruce seed production as measured in seed traps within stands containing both species. The coefficients of determination $\left(r^{2}\right.$ 's) were 0.92 and 0.93 , respectively $(n=6 ; p<0.05)$.

We should point out that the measured basal area $\left(\mathrm{B}_{\mathrm{D}}\right)$ applies primarily to dominant and co-dominant spruce and fir. Subcanopy trees produce far fewer seeds per basal area than expected from equation (1); i.e., seed production is dependent on light receipt as well as tree size (Greene et al. 2002).

\section{Juvenile survivorship}

The greatest age-specific annual mortality experienced by a cohort occurs in the two years from seed abscission to the end of the second summer (see the review by Greene et al. 1999). To simplify seedbed effects on juvenile survivorship, we divide upland substrates into two groups: optimal (thin humus and mineral soil) and poor (fibric organic layers of litter or nonSphagnum mosses) (Coates et al. 1994, Greene and Johnson 1998, Wright et al. 1998a). Following Greene and Johnson (1998), the cumulative juvenile survivorship (S) over the first two or three years (at which point the age-specific survivorship asymptotically approaches 1.0) can be expressed as

[2a] $\mathrm{S}_{\mathrm{o}}=0.43\left(1-\exp \left(-1.83 \mathrm{~m}_{\mathrm{s}}^{0.43}\right)\right.$ (optimal; $\mathrm{r}^{2}=0.89 ; \mathrm{N}=20$ species)

[2b] $\mathrm{S}_{\mathrm{p}}=0.43\left(1-\exp \left(-0.33 \mathrm{~m}_{\mathrm{s}}^{0.77}\right)\right.$ (poor; $\mathrm{r}^{2}=0.98 ; \mathrm{N}=5$ species)

where $\mathrm{m}_{\mathrm{s}}$, as before, is seed mass $(\mathrm{g})$ and the coefficient 0.43 is the expected mean survivorship through the granivory stage (i.e., on average $57 \%$ of the abscised seeds are eaten). For smallseeded species such as white spruce or balsam fir, equation (2) argues that there is about a 30-fold difference in survivorship between optimal and poor seedbeds.

As shown by Greene and Johnson (1998), the expected cumulative survivorship in equation (2) for white spruce shows large temporal variation (but this is much less than the temporal variation in seed production). A reliability of $84 \%$ for these estimates of survivorship requires that we reduce the survivorship values in equation (2) by 2.5 times (one standard deviation below the mean). As there are too few studies on direct seeding of balsam fir to allow characterization of the temporal variation in juvenile survivorship, we argue, without evidence, that the same reduction (2.5 times) as for white spruce is correct; i.e., fir survivorship is as variable as that of spruce. Dividing equation (2) by 2.5, and assuming that seed mass $\left(\mathrm{m}_{\mathrm{s}}\right.$ in grams) is 0.0022 for white spruce and 0.0065 for fir, then we have (as listed in Table 1) a survivorship of 0.021 on optimal and 0.00052 on poor seedbeds for white spruce, or 0.0324 on optimal and 0.0012 on poor seedbeds for fir.

\section{Recruitment density and stocking proportion}

By coupling equation (1) and the survivorship values for balsam fir and white spruce on the different seedbeds with a seed dispersal term, one can provide an estimate of the minimal seedling density $71 \%$ of the time at any particular distance from an area source. While tested dispersal functions exist for predicting regeneration density (e.g., Greene and Johnson 1996, Stewart et al. 1998), we adopt a simpler approach here. We express stocking proportion as a function of seedling density on a large spatial scale using published forestry records. Thus, we make the assumption that the effects of clumping of conspecific sources, the constraints of dispersal, and any clumping of the optimal seedbeds will be implicit in the empirical relationship, and we can, therefore, bypass explicit consideration of the spatial positions of regeneration survey plots and of individual source trees.

We can develop estimates of stocking for natural and advance regeneration from the literature. The expectation for stocking success ( $\mathrm{T}$, where $\mathrm{T}$ is the proportion of survey plots of size $\mathrm{A}\left(\mathrm{m}^{2}\right)$ with one or more conifers) given a purely random arrangement of stems would be a Poisson function of $F_{D}$ (recruits $/ \mathrm{m}^{2}$ ):

[3a] $\mathrm{T}=1-\mathrm{e}^{-\mathrm{AFD}}$

To account for the clumping so typical of smaller stems, we modify the Poisson as:

[3b] $\mathrm{T}=1-\mathrm{e}^{-\mathrm{a}(\mathrm{AFD}) \mathrm{b}}$ 
Table 1. Default values for various parameters discussed in the modelling section. $\mathbf{A R}=$ advance regeneration; $\mathbf{P H R}=$ post-harvest regeneration

\begin{tabular}{lcc}
\hline & $\begin{array}{c}\text { Alberta } \\
\text { (white spruce) }\end{array}$ & $\begin{array}{c}\text { Quebec } \\
\text { (balsam fir) }\end{array}$ \\
\hline Plot size $\left(\mathrm{m}^{2}\right.$ ) & $\mathrm{A}=10$ & $\mathrm{~A}=4$ \\
Survival on optimal seedbeds* & $\mathrm{S}_{\mathrm{o}}=0.0324$ & $\mathrm{~S}_{\mathrm{o}}=0.021$ \\
Survival on poor seedbeds* & $\mathrm{S}_{\mathrm{p}}=0.0012$ & $\mathrm{~S}_{\mathrm{p}}=0.00052$ \\
Seed size (grams) & $\mathrm{m}_{\mathrm{s}}=0.0065$ & $\mathrm{~m}_{\mathrm{s}}=0.0022$ \\
AR survival on skidpaths & $\mathrm{S}_{\mathrm{k}}=0.19$ & $\mathrm{~S}_{\mathrm{k}}=0.21$ \\
AR survival on non-skipaths & $\mathrm{S}_{\mathrm{n}}=0.62$ & $\mathrm{~S}_{\mathrm{n}}=0.44$ \\
Power-law intercept (AR) & $\mathrm{a}_{\mathrm{AR}}=1.0$ & $\mathrm{a}_{\mathrm{AR}}=0.37$ \\
Power-law exponent (AR) & $\mathrm{b}_{\mathrm{AR}}=1.0$ & $\mathrm{~b}_{\mathrm{AR}}=0.69$ \\
Power-law intercept (PHR) & $\mathrm{a}_{\mathrm{PHR}}=0.48$ & $\mathrm{a}_{\mathrm{PHR}}=0.48$ \\
Power-law exponent (PHR) & $\mathrm{b}_{\mathrm{PHR}}=0.90$ & $\mathrm{~b}_{\mathrm{PHR}}=0.90$ \\
\hline
\end{tabular}

Note: to achieve $84 \%$ reliability, mean survivorship values have been decreased by 2.5 times.

with a and b empirical coefficients dependent on the degree of clumping. Using post-harvest recruitment data sets (varying sites) for fir and (small) white spruce from Jarvis (1966), Pike and Waldron (1966), Griffin and Carr (1973), Fox et al. (1984: only the two more recent clearcuts listed in that paper), and Timoney and Peterson (1996) we obtain:

[3c] $\mathrm{T}=1-\exp \left(-0.52\left(\mathrm{~F}_{\mathrm{D}} \mathrm{A}\right)^{0.90}\right)$

(post-harvest recruitment) $\left(n=29 ; r^{2}=0.93\right)$.

By contrast, using the data for advance regeneration of fir (mainly) and white spruce (both pre- and post-harvest evaluations) from Roberts and Dong (1993), Timoney and Peterson (1996), and Kneeshaw and Messier (unpublished data), we have:

[3d] $\mathrm{T}=1-\exp \left(-0.44\left(\mathrm{~F}_{\mathrm{DAR}} \mathrm{A}\right)^{0.69}\right)$
$\quad$ (advance regeneration recruitment)

$\left(\mathrm{n}=35 ; \mathrm{r}^{2}=0.95\right)$ and $\mathrm{F}_{\mathrm{DAR}}$ refers to the density of the advance regeneration.

The advance regeneration stems are more clumped than the post-harvest recruits. For example, with $\mathrm{AF}_{\mathrm{D}}=\mathrm{AF}_{\mathrm{DAR}}=2$ stems $/ \mathrm{m}^{2}$, the expected stocking is $0.62(62 \%)$ for post-harvest recruitment but only $0.51(51 \%)$ for advance regeneration. To achieve $84 \%$ reliability for this estimate, we lower the empirical intercept within the exponential terms above by one standard error. Thus, from equation (3c) we reduce the intercept from 0.52 to 0.48 ; likewise, in equation (3d) the value is reduced from 0.44 to 0.37 . These reduced values are listed in Table 1 with the other default values.

However, the taller white spruce advance regeneration stems typical of western mixed forests do not appear to be so markedly clumped as in the east. Given that aspen canopies are less opaque in the west than in the east (Lieffers et al. 1999), we believe one-sided competition (Weiner and Thomas 1986) breaks down the clumped distribution. Thus, we will portray white spruce advance regeneration as randomly distributed, with the intercept and exponent (Table 1) set equal to 1.0 (i.e., a standard Poisson distribution, as above). We admit, however, that we can find no data sets on the spatial distribution of taller white spruce advance regeneration in the understory of western mixedwood forests to test this assumption.

Equations (1) through (3) permit us to state the required combinations of seed-source basal area (expressed as $\mathrm{m}^{2} / \mathrm{m}^{2}$ ) and site preparation intensity that will permit natural regeneration
Table 2. Expected survival of non-merchantable advance regeneration after careful harvesting. The time period is the harvest and the subsequent first year. Data are from northern-eastern Ontario

\begin{tabular}{lcc}
\hline Stem size & $\begin{array}{c}\text { skidpath } \\
\text { survival }\end{array}$ & $\begin{array}{c}\text { non-skidpath } \\
\text { survival }\end{array}$ \\
\hline height $<50 \mathrm{~cm}$ & 0.23 & 0.46 \\
$50<$ height $<250 \mathrm{~cm}$ & 0.36 & 0.75 \\
$>250 \mathrm{~cm}$ but dbh $<10 \mathrm{~cm}$ & 0.16 & 0.80 \\
\hline
\end{tabular}

to meet a stocking objective. Nonetheless, it should be remembered that some steps in the derivation of these equations have relied on inadequate data sets. For example, there are relatively few long-term seed production studies for white spruce and balsam fir, and our equation (1) is a general argument based on many North American species. Further, in two cases, due to a lack of empirical data we were forced to make assumptions (that the temporal variation in cumulative survivorship of fir is similar to spruce and that tall advance regeneration of white spruce in the west is randomly distributed).

\section{Mortality of advance regeneration following careful harvesting}

Earlier harvesting systems with strip-cuts or clearcuts that made no attempt to protect small advance regeneration permitted the survival of only $10-30 \%$ of the small fir and white spruce stems in New Brunswick and Quebec (Frisque et al. 1978, Harvey and Bergeron 1989, McInnis and Roberts 1994), and less than $20 \%$ (V. Lieffers, pers. obs.) in Alberta. By contrast, systems designed to protect advance regeneration (e.g., MacDonnell and Groot 1997) report much higher survival rates after logging (32-80\%). We use data from Ontario (Table 2) showing differences in mortality based on seedling size that we think are typical of fir as well as white spruce where the prescription calls for protecting advance regeneration.

Most mortality of shorter stems occurs during the harvesting operation and first post-harvest summer. Subsequently, while some stems continue to die for the next few years due to injuries or exposure, age-specific survival after the first year is much higher than depicted in Table 2. Ruel et al. (1995) reported survival of about $75 \%$ during the first few years after the harvest for balsam fir and black spruce whereas A. Groot (unpublished data) placed the survival at about $90 \%$. Research by Lieffers et al. (1993a) suggests that white spruce is little affected by changes in exposure (however these authors do not provide mortality estimates). We use the median figure of $82.5 \%$ for all size classes for the subsequent cumulative survival over the next few years, although this survivorship may well be species-specific, sizespecific, or region-specific and clearly requires further study.

For the east, an unpublished study by D. Kneeshaw and C. Messier of the stem sizes of advance regeneration of fir and white spruce in western Quebec suggests that the very small stems $(<50$ $\mathrm{cm}$ height) in Table 2 constitute $75 \%$ of all the advance regeneration, the next larger class $(50<$ height $<250 \mathrm{~cm})$ comprises $25 \%$, and that taller non-merchantable stems represent a negligible fraction. Weighting the results in Table 2 by these proportions, and then multiplying by 0.825 to account for subsequent survival, we have a survivorship of 0.21 ( $\mathrm{S}_{\mathrm{k}}$ in Table 1 ) on the skidpath and $0.44\left(\mathrm{~S}_{\mathrm{n}}\right.$ in Table 1) on the non-skidpath area.

The west is different. Subcanopy white spruce in Alberta's mixed stands are much taller on average than are fir in the east. 
An unpublished study by Lieffers, Stadt and Navratil, showed that the smallest height class $(<50 \mathrm{~cm})$ had $11 \%$ of the stems, the next tallest class $(50 \mathrm{~cm}<$ height $<250 \mathrm{~cm})$ comprised $32 \%$ of the stems, while the tallest stems made up 58\%. In an early study of some of the first understory protection logging in Alberta, it was suggested that about $20 \%$ of the spruce was lost in non-skid areas (Navratil et al. 1994). One may surmise that survival has increased as skills have improved, but without current data we will use the results in Table 2. Thus, as before, weighting the size-related mortalities in Table 2 by the relative frequency of the size classes, we arrive at average figures (from Table 1) of 0.19 on the skidpath and 0.62 on the non-skidpath. Skidpath survival is less in the west than in the east because the taller spruce have higher mortality than the shorter fir. By contrast, non-skidpath survival is substantially greater in the west because, again, the average stem is taller, and taller seedlings are likely to be broken by machinery.

Mortality of taller stems due to windthrow appears to be, generally, quite small when adequate aspen leave strips are retained in windy areas. G. Grover of Alberta-Pacific (unpublished data) found windthrow losses of only $0.2-3.4 \%$ over a four-year period for carefully harvested sites. Such negligible losses can be ignored in the model.

Reliance on advance regeneration via techniques such as CPRS (Coupe avec protection de la régénération et des sols) or CLAAG (Careful logging around advance growth) has been successful (met the stocking standard a few years after harvest) only about $70 \%$ of the time in Ontario and in Québec (A. Groot and D. Cormier, pers. obs.; we know of no summary data). However, it can be argued that a large proportion of the failures results from cursory evaluation of the suitability of stands prior to harvesting and inadequate amounts of advance growth. We see no reason why reliance on advance regeneration cannot meet the stocking standard at least $84 \%$ of the time given suitable pre-harvest evaluation.

\section{Issues associated with underplanting}

Planting white spruce under maturing aspen stands will likely play a significant role in future mixedwood silvicultural systems (Lieffers et al. 1996a). Understory planting should decrease seedling damage due to frosts, root rot, terminal weevils, and spruce budworm (Su et al. 1996, Taylor et al. 1996, Man and Lieffers 1999). Further, as argued by Lieffers et al (1999) it can reduce site preparation and weeding costs on sites where overstory removal will lead to recruitment of a dense layer of bluejoint reed grass (Calamagrostis canadensis), raspberry (Rubus species) or mountain maple (Acer spicatum). A final advantage is that it provides greater long-term tree retention and will thus have positive impacts on visual quality objectives, and will help maintain mixed stands in the managed landscape.

Shelterwood harvests may provide the best compromise between clearcuts and underplanting closed stands in terms of light levels and moderated microclimate (Man and Lieffers 1999). Groot (1999) argued that maximum growth of spruce occurred at 70-80\% light while others suggest that height growth of white spruce and fir reaches a plateau above about $40 \%$ of full light levels (Lieffers and Stadt 1994, Wright et al. 1998b, Coates and Burton 1999).

\section{Required conditions for understory planting to be successful.}

The first criterion for successful understory planting is adequate survival of the planted trees until growing conditions are improved by partial or complete overstory canopy removal (Coates 2000). Spruce should be planted under aspen 10-20 years prior to time of harvest of the aspen. We expect unacceptably high rates of mortality of planted understory trees at light levels of less than about $20 \%$ full sun based on studies by Kobe and Coates (1997) and Wright et al. (1998b), in northwestern British Columbia for subalpine fir (Abies lasiocarpa (Hook.) Nutt) and natural hybrid spruce (crosses of white spruce and Sitka spruce (Picea sitchensis (Bong.) Carr.). This precludes underplanting extremely dense juvenile aspen stands in the west where subcanopy radiance may be as low as 5\% (Pinno 2000). Any situation with tall and dense understory shrub and grass layers, particularly green alder, beaked hazelnut, mountain maple or blue joint reed grass is also unlikely to deliver enough light at the seedling level ((Messier et al. 1998, Lieffers et al. 1999).

In operational trials, mortality rates of underplanted seedlings with good stock have generally been low: $<4 \%$ (G. Grover, pers. obs.; Tanner et al. 1996). Both frost damage and chlorosis of seedlings were also five to twenty times lower in seedlings planted in understories vs. clearcuts (Tanner et al. 1996, DeLong et al. submitted). Mortality after 20 years with poor stock has been somewhat higher (an average of $4 \%$ with one outlier of 70\%: DeLong 1997, DeLong et al. submitted).

Growth rates of spruces and firs are low in the understory when light levels are less than 30\%. Spruce height growth of $10 \mathrm{~cm}$ or more per year can be maintained under maturing aspen canopies in Alberta (Lieffers et al. 1996b; Ruel et al. 2000). This corresponds, generally to 40-80-year old aspen stands with 51-70\% cover or 800 stems/ha (DeLong 1997; G. Grover, pers. obs.), but of course, the main criterion is light availability rather than stand age. DeLong (1997) suggests that aspen stands with less than $1200 \mathrm{stems} / \mathrm{ha}$ or $35 \mathrm{~m}^{2} / \mathrm{ha}$ basal area would provide suitable light levels for adequate spruce height growth.

Wright et al. (2000) suggest fir and spruce will release after extended periods (10-40 years) of suppression: subalpine fir responded quickly to increased light while the response of spruce was more gradual. These results for spruce are supported by Yang (1989) where, following release, spruce height growth responded slowly for the first five years but an average $42 \%$ increase over controls was observed after 30 years. The greatest release occurred in trees $2-6 \mathrm{~m}$ in height and between 14 and 40 years of age (Yang 1989). Studies of other conifers have shown height growth release occurring 2-4 years after overstory removal (McCaughey and Ferguson 1988, Kneeshaw et al. 1998, Murphy et al. 1999, Kneeshaw et al. 2002).

Understory spruce should have a minimum height of $2.5 \mathrm{~m}$ before harvest of the aspen (Johnson 1986) to ensure that the spruce will be large enough to successfully compete with aspen root suckers and/or bluejoint reed grass, and that they will be seen by feller-buncher operators. Yang (1989), however, suggests spruce should be $3.4 \mathrm{~m}$ in height to avoid overtopping by aspen suckers. Spruce seedling height in experimental projects established by the Canadian Forest Service in the west are 1.9-2.4 m 20 years after underplanting (DeLong, 1997). Operational trials with current large seedling stock suggest that greater height growth may be obtained, one trial showing an average white spruce seedling height of $70 \mathrm{~cm}$ after five growing seasons (G. Grover, pers. obs.). Since light levels under mature aspen are somewhat lower in the east (Messier et al. 1999), we expect growth to be less and rotation periods longer. 
Browsing damage by snowshoe hares (Radvanyi, 1987) and grouse (K.D. Coates, pers. obs.) may also be problematic for underplanted spruce. Suggestions to reduce this problem include using bareroot stock (which is less palatable than container stock) and not giving seedlings the last dose of fertilizer before shipping. Also, gearing up planting programs immediately after peaks in hare or grouse populations may allow successful establishment. Alberta-Pacific Forest Industries is also attempting to match underplanting operations with stand and adjacency characteristics that offer poor habitat conditions for snowshoe hares.

Finally, to be financially successful, this technique requires road access to all stands to be underplanted one to two decades before expected harvest of the aspen. This should not be a problem in subsequent rotations when road networks are established.

According to G. Grover (unpublished data), understory planting has met its management objectives (survivorship greater than $90 \%$, good annual height growth) in more than $95 \%$ of 20 trials during the interval 1994-1998. Most of the trials reported in the literature also suggest that mortality rates will be on the order of $5 \%$ or less if good growing stock is used (Tanner et al. 1996; DeLong et al. submitted).

\section{Modelling Results and Discussion}

In the following sections, we explore the relationship between the foregoing quantification and the required stocking objectives (full, moderate, and minimal as in Table 3). First, we examine the biotic limitations at the scale of the harvest block (e.g., is there enough basal area among the conifer seed sources to achieve, say, moderate stocking?). Second, we examine biotic limitations at the regional scale in relation to the stocking objectives (e.g., is dense advance regeneration sufficiently common in the west that foresters can frequently use it to achieve the desired stocking level?). We then turn to the costs/ha (stand scale) associated with each prescription. Imagining that the forester will rely on advance regeneration to whatever extent is possible, we then scale up to the harvest block by examining cost per scenario given a careful harvesting system (such as CPRS or CLAAG). Thus, at the end of the exercise we can compare the block-scale costs of the alternative prescriptions versus the convention of a clearcut followed by planting.

For the careful harvesting, we envisage 4.5 -m wide skidpaths separated by $10.5-\mathrm{m}$ wide non-skidpath areas. Thus, the skidpaths occupy $30 \%$ of the block (the proportion $\mathrm{p}_{\mathrm{k}}=0.3$ ) while the proportion for the non-skidpath area $\left(\mathrm{p}_{\mathrm{n}}\right)$ is 0.7 .

\section{Biotic Limitations on the Prescriptions}

Prescription 1: complete reliance on advance regeneration

Conditions: Let us assume a careful harvesting design (i.e., we are seeking to minimize damage to the small pre-harvest stems) with the $4.5-\mathrm{m}$ wide skid paths occupying $30 \%$ of the area, and that any non-harvested stems of spruce and fir will be too small to produce significant numbers of seeds. We have, from the modified Poisson equation $(3 \mathrm{c})$ :

$$
\begin{gathered}
\text { [4] } \mathrm{T}=\left(\mathrm{p}_{\mathrm{k}}\left(1-\mathrm{e}^{(-\mathrm{aAR}(\text { AFDARSk }) \mathrm{bAR}))}\right)\right. \\
+\left(\mathrm{p}_{\mathrm{n}}\left(1-\mathrm{e}^{-\mathrm{aAR}(\text { AFDARSn }) \mathrm{bAR}}\right)\right)
\end{gathered}
$$

where symbols are defined above and default values are provided in Table 1. Results are given in Fig. 1. From equation (4) we calculate that the pre-harvest density $\left(\mathrm{F}_{\mathrm{DAR}}\right)$ for full stock-
Table 3. Conifer stocking criteria (\% of plots having at least one acceptable seedling) for areas using a 10 or $4 \mathrm{~m}^{2}$ survey plot size. As only Alberta has set out quantitative standards for partial stocking options, the $4 \mathrm{~m}^{2}$ criterion is based on the new Alberta guidelines for minimal and moderate stocking (i.e., $37.5 / 60=50 / 80 ; 30 / 80=22.5 / 60$ )

Stocking criterion Stocking criterion

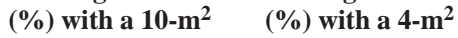

\begin{tabular}{|c|c|c|}
\hline $\begin{array}{l}\text { Minimal (pre-harvest } \\
\text { aspen-dominated mixed stand) }\end{array}$ & 30 & 22.5 \\
\hline $\begin{array}{l}\text { Moderate (pre-harvest } \\
\text { conifer-dominated mixed stand) }\end{array}$ & 50 & 37.5 \\
\hline Full & 80 & 60 \\
\hline
\end{tabular}

survey plot (Alberta) survey plot

ing $(60 \%)$ must be greater than 2.6 (26 000 stems/ha) with a survey plot size (A) of $4 \mathrm{~m}^{2}$ as required in Quebec. This result agrees tolerably well with the rule-of-thumb of Zelasny and Hayter (1991) that advance regeneration prior to harvest should be about 30000 stems/ha for black spruce (Picea mariana) or fir. There are no similar suggestions for white spruce in the east.

By contrast, in the west much lower densities are required because of the better survival of stems through the harvesting operation and because of the less clumped spatial distribution of stems. Full stocking $(80 \%)$ for Alberta $\left(\mathrm{A}=10 \mathrm{~m}^{2}\right)$ requires 4000 stems/ha. $50 \%$ stocking can be achieved with 1500 stems/ha, while $30 \%$ stocking requires 750 stems/ha. In these latter cases we can expect that a mixedwood forest will develop. Inspection of equation (4) leads to the following operational recommendations. Any technique that minimizes skidpath width or minimizes mortality on the skidpath areas will increase the stocking as most of the unstocked plots fall on the skidpaths.

For the less careful harvesting prior to the 1990s, where we might assume that the entire cut undergoes the mortality associated with skidpaths in the careful harvesting operation (Table 2), we thus require (if $\mathrm{A}=4$ ) about 50000 stems/ha prior to harvest, which agrees with Frisque et al. (1978) from New Brunswick and Quebec.

\section{Prescription 2: reliance on a mast year}

Conditions: we assume careful harvesting in an area with an adequate amount of spruce and/or fir seed trees. The schedule calls for; (1) determination that a mast year is occurring (This can be done in the preceding year by microscopic examination of buds taken from the tops of trees harvested in nearby stands or in the present year (May or June) by binocular examination of trees); (2) Understory scarification takes place in the period July to mid-September (i.e., before seed abscission begins); skidpaths are laid out at this time and no scarification takes place on the eventual skidpaths; scarification covers $35 \%$ of the block and thus, given that skidpaths occupy $30 \%$ of the block, the scarified portion is $50 \%$ of the non-skidpath part of the block; and (3) the harvest takes place in the winter when the great majority of seeds will already have abscised. It is assumed that no advance regeneration stems survive in the scarified areas.

Clearly, many of the regeneration survey plots will straddle the interface of the skidpath and the non-skidpath areas. To simplify the modelling, let us idealize the block as consisting of three proportions: $\mathrm{p}_{\mathrm{k}}=(4.5-\sqrt{\mathrm{A}}) / 15 ; \mathrm{p}_{\mathrm{n}}=(10.5-\sqrt{\mathrm{A}}) / 15$; and $\mathrm{p}_{\mathrm{nk}}=$ $(2 \sqrt{A}) / 15$ where $p_{k}$ is the proportion of survey plots consist- 


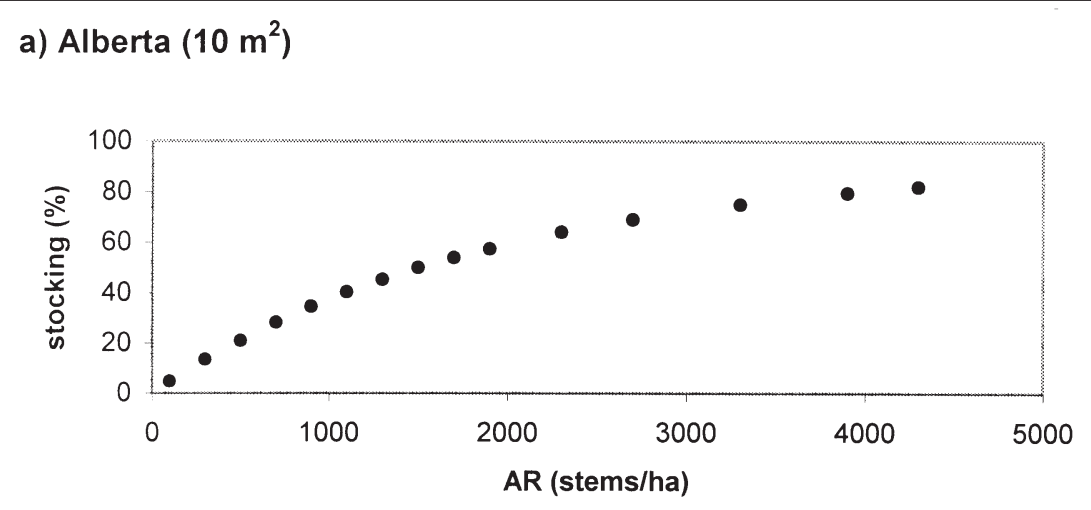

b) Quebec $\left(4 \mathrm{~m}^{2}\right)$

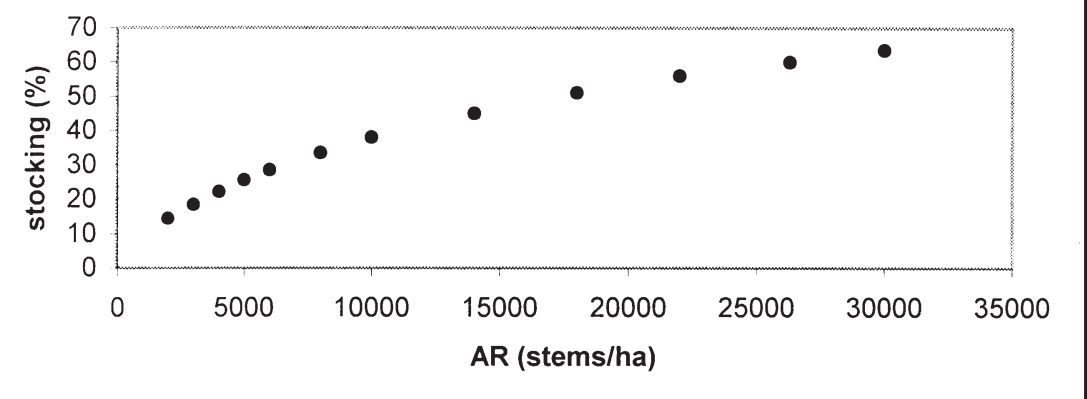

Fig. 1. Predicted post-harvest stocking versus pre-harvest advance regeneration density (AR in stems/ha) for (a) Alberta and (b) Quebec. ing solely of the skidpath, $\mathrm{p}_{\mathrm{N}}$ is the proportion consisting solely of the non-skidpath area (with $50 \%$ exposure of the optimal seedbeds); and the remainder $\mathrm{p}_{\mathrm{kn}}$ is an even mix of skidpath and non-skidpath. At the scale of the block,

$$
\text { [5] } \mathrm{T}=\mathrm{p}_{\mathrm{k}} \mathrm{X}_{1}+\mathrm{p}_{\mathrm{n}} \mathrm{X}_{2}+\mathrm{p}_{\mathrm{kn}} \mathrm{X}_{3}
$$

where the $X$ values are modifications of equation (4) for the relationship between plot area $(\mathrm{A})$, stem density (advance regeneration $\left(\mathrm{F}_{\mathrm{DAR}}\right)$ or post-harvest regeneration $\left.\left(\mathrm{F}_{\mathrm{DPHR}}\right)\right)$, and stocking $(\mathrm{T}) . \mathrm{F}_{\mathrm{DAR}}$ is multiplied by the assumed survivorship on skidpaths $\left(\mathrm{S}_{\mathrm{k}}\right)$ and non-skidpaths $\left(\mathrm{S}_{\mathrm{n}}\right)$ during the harvest operation while $\mathrm{F}_{\text {DPHR }}$ is the product of the seed supply (in turn, a function of seed mass and conifer basal area) and the juvenile survivorship on optimal $\left(\mathrm{S}_{\mathrm{o}}\right)$ or poor $\left(\mathrm{S}_{\mathrm{p}}\right)$ seedbeds. (The default values are given in Table 1.)

$$
\begin{aligned}
& \mathrm{X}_{1}=1-\mathrm{e}^{-\mathrm{aAR}(\text { AFDARSk)bAR} ;}
\end{aligned}
$$

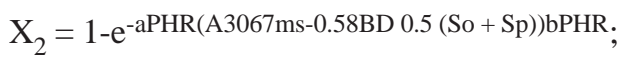

$$
\begin{aligned}
& \mathrm{X}_{3}=1-\mathrm{e}^{\mathrm{aPHR}}(\mathrm{A} 3067 \mathrm{~ms}-0.58 \mathrm{BD} 0.25(\mathrm{So}+\mathrm{Sp})) \\
& \left.\left.+\left(\mathrm{AF}_{\mathrm{DAR}} 0.5 \mathrm{~S}_{\mathrm{k}}\right)\right)^{\mathrm{bPHR}}\right)
\end{aligned}
$$

Note that in $\mathrm{X}_{3}$ we have, for simplicity, used the post-harvest equation (3c) for the combined advance regeneration and post-harvest seedlings as we argue the latter will comprise the great majority of the stems.
From the equations above it can be seen that the stocking proportion will rise with an increase in either $\mathrm{F}_{\mathrm{DAR}}$ (advance regeneration density in stems per $\mathrm{m}^{2}$ ) or $\mathrm{B}_{\mathrm{D}}$ (basal area per area in $\mathrm{m}^{2}$ ). Solving iteratively to find the required $\mathrm{B}_{\mathrm{D}}$ and $\mathrm{F}_{\mathrm{DAR}}$ given the survey plot area $(\mathrm{A})$ and the required minimal $\mathrm{T}$ for full stocking success ( $60 \%$ with $A=4 \mathrm{~m}^{2}$ and $80 \%$ with $A=10 \mathrm{~m}^{2}$ ), we plot the results in Fig. 2. Fig. 2 assumes that the species is white spruce in the west and balsam fir in the east.

With $\mathrm{F}_{\mathrm{DAR}}=0$, the required basal area/ha is, in Alberta, $6.6 \mathrm{~m}^{2} /$ ha for full stocking $(80 \%), 2 \mathrm{~m}^{2} /$ ha for moderate stocking $(50 \%)$, and $1 \mathrm{~m}^{2} /$ ha for minimal stocking $(30 \%)$. The corresponding values for fir in Quebec are almost twice as high. This is because spruce is expected to have somewhat higher fecundities than fir, and because it is somewhat easier to satisfy a given standard with $\mathrm{A}=10 \mathrm{~m}^{2}$ (Alberta) than $\mathrm{A}=4 \mathrm{~m}^{2}$ (Quebec). Little advance regeneration survives on skidpaths and all of it is removed in scarification passes. In a sense, this prescription is a seed-tree retention system (e.g., 75 trees/ha each with a $40-\mathrm{cm}$ dbh provides about the required basal area/ha for full stocking). However, as the seed is dispersed before the harvest in winter, all of the trees in the cutover can be removed, and thus it is a very brief retention interval.

Now, the main source of unreliability with sexual regeneration after harvest (ignoring for the moment competition problems) is masting behaviour, but of course this prescription aims to eliminate that source of uncertainty. Other uncertainties are fluctuations in populations of seed-eaters and weather (especially extended drought). However, our derivation of 
a) Quebec

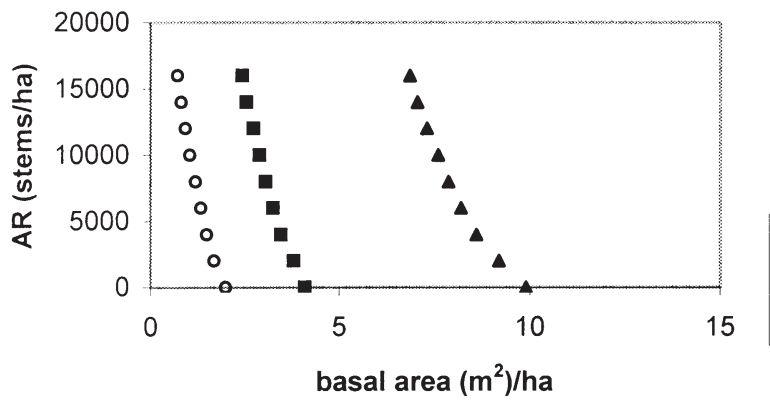

b) Alberta

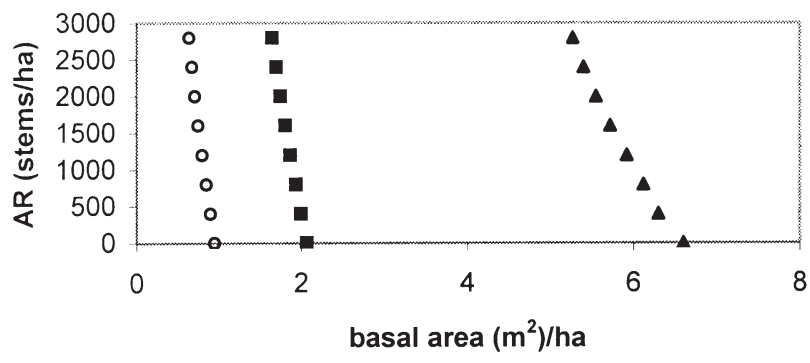

- stocking $=30 \%$

- stocking $=50 \%$

$\Delta$ stocking $=80 \%$
Fig. 2. Required advance regeneration density (AR in stems/ha) as a function of basal area/area $\left(\mathrm{m}^{2} / \mathrm{ha}\right)$. Fig. $2 \mathrm{a}$ is for Quebec (i.e., a jurisdiction with a $4-\mathrm{m}^{2}$ survey plot), while Fig. $2 \mathrm{~b}$ is for Alberta (a plot size of $10 \mathrm{~m}^{2}$ ). The stocking criteria (full, moderate, minimal) are scaled to the plot size as in Table 3. equation (3) took this variation into account. In short, sufficiently high seedling densities should be obtained in $71 \%$ of the attempts. Thus, the reliability of this approach should be quite good. Where the prescription has been for scarification prior to harvest, but during a mast year (e.g., Lees 1963, 1970; Desjardins 1988; Stewart et al. 2000), this approach has resulted in very high seedling densities on the scarification paths. The main problem with the successful application of this approach is not the biology but the geometry ${ }^{11}$ : if the distances between the scarified strips becomes too wide, then many survey quadrats contain unprepared seedbeds and thus have few seedlings.

\section{Prescription 3: seeding following the harvest}

Conditions: Scarification takes place in the autumn or spring after the harvest. We assume it results in $35 \%$ mineral soil and humus exposure $\left(\mathrm{p}_{\mathrm{sc}}=0.35\right)$. Seeding should be done after snowmelt but before early June (when germination usually begins). We assume 80-95\% germinability for cleaned seed and our example uses white spruce rather than fir. Invoking equation (3c), we have:

\footnotetext{
${ }^{11}$ For example if $35 \%$ of the block (parallel strips) is scarified then this does not mean $65 \%$ will be unstocked. Imagine $0.8-\mathrm{m}$ wide scarified strips, the inter-strip areas are only $1.49 \mathrm{~m}$ wide $(0.35=0.8 /(0.8+1.49))$. It becomes impossible to lay down a $2 \times 2-\mathrm{m}$ quadrat and not sample at least some of the prepared ground. Similarly, one could imagine one large band that is scarified with the rest remaining unscarified in which case many quadrats would be outside the area of prepared ground.
}

[6] $\mathrm{T}=1-\mathrm{e}^{(-\mathrm{aPHR}(\mathrm{AQD}[(\mathrm{pscSo})+((1-\mathrm{psc}) \mathrm{Sp})] \mathrm{bPHR}))}$

where $Q_{D}\left(\right.$ seeds $\left./ \mathrm{m}^{2}\right)$ is now construed as an aerial sowing rate and $\mathrm{T}$, as before, is the stocking proportion. Results are presented in Fig. 3. From equation (6) we obtain a required sowing rate of 670000 seeds/ha for full stocking with a $4-\mathrm{m}^{2}$ plot (A) or 500000 seeds/ha with a $10-\mathrm{m}^{2}$ plot. The required sowing rates are therefore enormous. These rates of scarification and sowing are much higher than foresters have usually tried. More typically, scarification intensity is about $17 \%$ for a wide variety of machinery (Fleming et al. 1987) and sowing rates (during the last few decades) have been about 50-300 thousand seeds/ha. It is thus not surprising that, as summarized by Waldron (1974), direct seeding trials with white spruce have tended to be disappointing.

Indeed, with only $17 \%$ of the block being scarified, it would require 1.4 million seeds/ha $(A=4)$ for full stocking $71 \%$ of the time. As shown in Fig. 3, required sowing rates for reduced stocking standards are smaller but still substantial, e.g., in Alberta with a $10-\mathrm{m}^{2}$ survey plot, $30 \%$ stocking would require sowing about 100000 seeds/ha.

Note that we have not considered any role for advance regeneration because we primarily see this prescription used on harvest blocks where there is little conifer advance regeneration.

We believe that use of a scarifier-seeding machine is to be preferred to aerial application. Seeds are dropped behind the scarifier directly on the furrow instead of being broadcast. In 


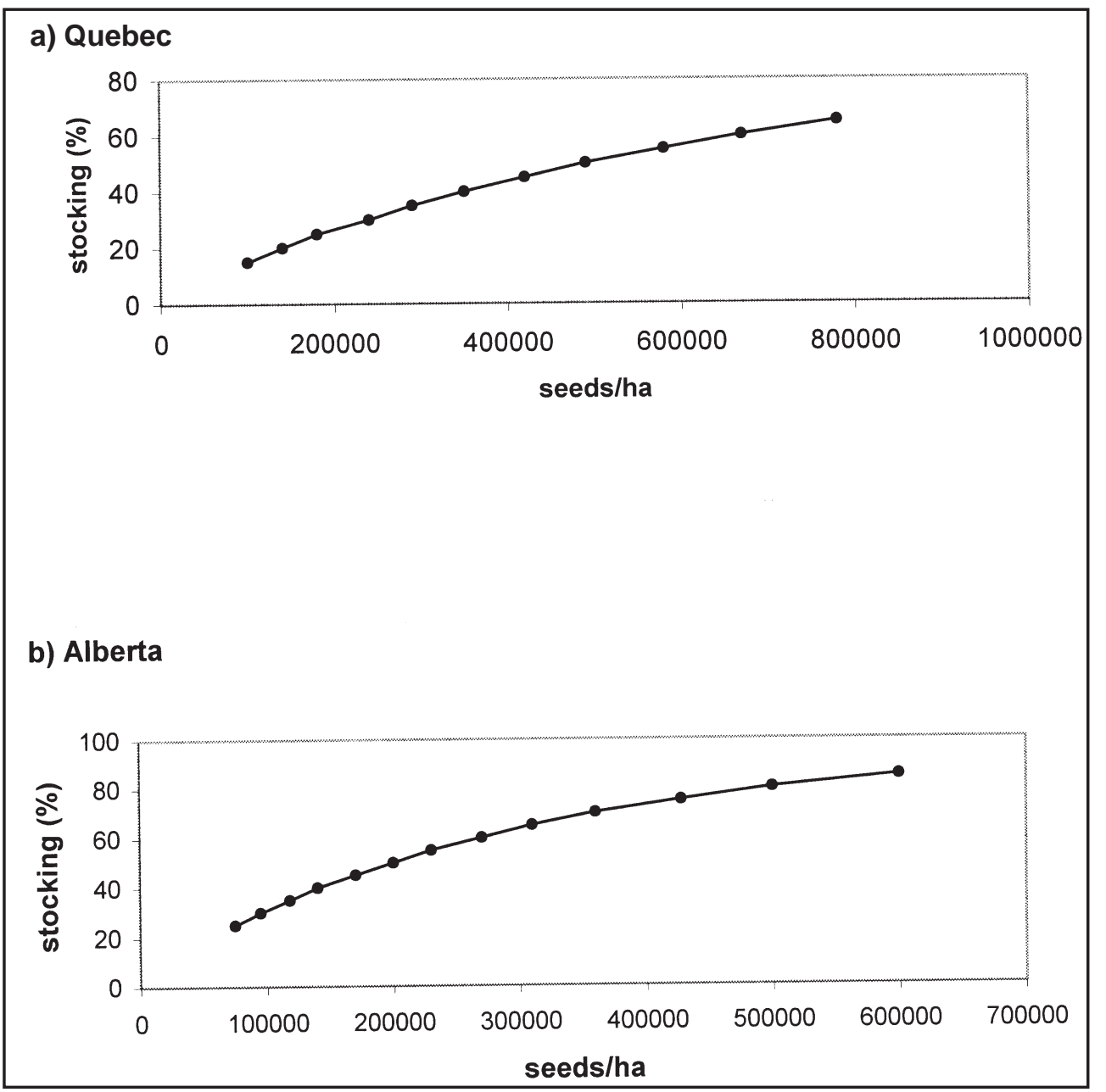

Fig. 3. Stocking percentage as a function of the density (\#/ha) of seeds sown aerially. Results are for white spruce given the survey plot size in (a) Quebec and (b) Alberta. Full stocking is assumed.

Quebec, S. Boris and C. Calogeropoulos (unpublished data) attached a scarifier-seeding machine to an all-terrain vehicle and obtained $6 \%$ first-year survivorship (from sowing to the end of the first summer) of sown white spruce on very thick, disked leaf litter (no mineral soil was exposed) under an intact aspen stand. (Note: 6\% is slightly above the mean value expected from equation (3c) above.) This direct sowing would reduce seed use and cost by two-thirds as seeds are sown only on optimal seedbeds and these constitute $35 \%$ of the block. Further, the scarifier/seeder provides a more even distribution of seeds in the scarified strips than broadcast seeding. This may be a useful alternative to understory scarification in a mast year (Prescription 2) when there is insufficient conifer basal area per ha or where forest managers want to free themselves of the planning constraint imposed by the unpredictability of mast years.

Finally, we consider direct seeding of any kind to be inappropriate where bluejoint reed grass is expected to engulf the small seedlings, and thus one would require repeated weeding episodes. Our direct seeding prescriptions assume only competition from suckering aspen that can be addressed by a subsequent weeding/thinning operation.

\section{Prescription 4: understory planting}

Conditions: An aspen stand should be about 20 years from planned logging and the manager wishes to increase the conifer component in the next cohort. Light transmission at seedling height should be $>25 \%$ full radiance with no serious pre-har- vest competition problems so that the operator is assured of low mortality and acceptable growth rates.

\section{The Available Landbase in Relation to the Biotic Constraints}

In what follows we discuss the likelihood that the above silvicultural practices might be applied, given the biotic constraints noted above. We limit the evaluation to mesic stands older than 40 years.

\section{Conifer basal area}

Conifer basal area is usually available from forest inventories. In eastern Canada much of the landbase will have a coniferous basal area greater than our limits (i.e., 10,4 or $2 \mathrm{~m}^{2} /$ ha corresponding to the requirements for full, moderate, or minimal stocking in the absence of any augmenting advance regeneration), and thus the prescription for reliance on a mast year should have wide applicability. For example, in the Abitibi region of Quebec, 25\% of the landbase (mesic, older than 40 years) has conifer basal area (mostly fir) exceeding $10 \mathrm{~m}^{2} / \mathrm{ha}, 51 \%<10 \mathrm{~m}^{2} / \mathrm{ha}$, and $25 \%$ is pure hardwood forest (unpublished data, Jean Noël, Quebec Ministry of Natural Resources). As the conifers have slow juvenile growth, older stands usually have greater conifer basal area.

In the west (to use an example from Alberta Pacific's Forest Management Area in Alberta), areas where the white spruce basal area exceeds $7 \mathrm{~m}^{2} /$ ha (i.e., the value corre- 
sponding to full stocking) comprise about $26 \%$ of the total. This is similar to that found in the east, at least for the two areas that were compared. In summary, the prescription for reliance on a mast year may vary widely from one forest management unit to another, but may be all that is required on one quarter of the landbase. Only a small proportion of the landbase will not meet the basal area standards necessary to achieve a minimal conifer stocking and a mixed stand condition.

\section{Advance regeneration density}

The proportion of the mixedwood landbase on older mesic sites in the east that barely satisfies the full stocking criterion (>26000 stems/ha) is more difficult to appraise because advance regeneration density has not been a standard measurement in forest inventories. However, extrapolating from the data of Arnup (1996) in eastern Ontario, fir (vastly more common than white spruce) advance regeneration will exceed 26000 stems/ha (the minimum for full stocking) on about $10 \%$ of the landbase. Further, Arnup's (1996) data indicate that an additional 40\% of the landbase would have $10000<\mathrm{F}_{\mathrm{DAR}}<26000$ stems/ha (the range, recall, for moderate stocking levels). Thus, we estimate that managers can rely solely on advance regeneration for about $70 \%$ of the area. This proportion is greater in Quebec where Doucet (1988) found that over half the forests with even a modest fir component had advance regeneration densities exceeding $20000 \mathrm{stems} / \mathrm{ha}$, and likewise over half the hardwood-dominated stands had at least 6000 conifer stems/ha (minimal stocking required at least $4000 \mathrm{stems} / \mathrm{ha}$ ).

As for the west, while we have no data sets as useful as that of Arnup (1996) or Doucet (1988), there is little doubt that advance regeneration of white spruce occurs at lower densities (Navratil et al. 1994). Correspondingly, the required densities with these taller, more randomly distributed stems, is a good deal lower $(4000,1500$, and 750 stems/ha for full, moderate, or minimal stocking, respectively). Data from four management units in western Alberta suggest, however, that only a small proportion of the hardwood landbase $(<2 \%)$ would have more than the 1500 stems/ha that we suggest would be necessary for moderate to full stocking. Another 4\% would meet the minimum stocking standards. These data suggest that the use of white spruce advance regeneration would only be appropriate on a relatively small proportion of the landscape. Even relaxing the density interval to 100 from 750 advance regeneration stems/ha would only add another $13 \%$ of the hardwood landbase.

In summary, reliance on advance regeneration (especially in combination with fill planting) can be widely practised in the east (and indeed presently is widely practised). In the west, full stocking would be an extremely rare prescription, while moderate and especially minimal standards may be met on some small fraction of the landbase.

\section{Light transmission}

The prescription for underplanting calls for light transmission $>25 \%$ at $1 \mathrm{~m}$ height and without dense herbaceous or woody competition below that height. The age for underplanting aspen stands is 40 to 50 years assuming planting is done 20 years prior to the aspen harvest at 60 to 70 years. The reader is warned that the paucity of light measurements in mixedwoods makes our estimates of regional differences below quite speculative.

We expect light levels to be much lower in aspen stands in the east than in the west because (1) eastern stands are older and have a higher coniferous component (Bergeron 2000); (2) with the exception of fertile sites in British Columbia, canopy aspen are much larger in the more humid east and have more opaque crowns (Messier et al. 1998); and (3) shade tolerant shrubs (especially mountain maple) are a more common understory component. Just below eastern aspen crowns, light levels in the Abitibi region of western Quebec are between 10 and 20\% (Messier et al. 1998. D'Astous 2000) but competitors such as mountain maple will often leave very little light (much less than $10 \%$ ) at planting height. Extrapolating from the Abitibi data, we think that less than $5 \%$ of the immature mixed or monospecific aspen stands in the east will satisfy the light transmission criterion. In the west, however, Lieffers and Grover (pers. obs.) suggest that half of the maturing aspen stands (> 60 years) and up to $30 \%$ of younger (30-40-year old) stands would satisfy the light constraint.

\section{Comparative Costs/ha and Scenario Costs}

Here we compare the costs of the conventional clearcutting/planting prescription with the alternative prescriptions. We do not discount costs as a function of time of application, nor are the incremental harvesting costs (relative to large clearcuts) taken into account.

The following per ha costs were calculated using Interface, a decision-support software developed by FERIC (Forest Engineering Research Institute of Canada) for the analysis of harvesting and regeneration costs. The exception to our reliance on this software is for the costs of understory planting, which were based on the operational experience of $\mathrm{G}$. Grover in Alberta. Dollar figures are 1999 Canadian dollars.

\section{Costs/ha}

Mechanical scarification via disk-trenching of clearcuts is assumed to cost $\$ 200 /$ ha to scarify about $35 \%$ of the ground. Mechanical understory scarification with a small bulldozer equipped with a piling-rake (35\% exposure of mineral soil and humus) is $\$ 400 /$ ha while an excavator would be more expensive.

It is assumed that understory planting sites have been chosen for minimal grass and shrub competition, and, since the harvest will take place 10-20 years later when the planted stems are well above any potential competitors, there is no need for site preparation except boot-screefing.

For conventional planting of 2500 stems per hectare after a clearcut, we assume \$700/ha (regular container stock (\$0.10/seedling), and a planting cost of $\$ 0.18 /$ seedling). In Alberta, G. Grover has used a larger planting stock (410 and 415B: $\$ 0.25 /$ seedling) with planting costs of $\$ 0.30 /$ seedling for underplanting. As the future (pre-marked) skid-trails need not be planted, planting density for underplanting is typically about 1500 seedlings/ha, and therefore a total planting cost of $\$ 825 /$ ha is expected. For simplicity, we assume fill-planting costs will be similar to conventional plantations.

For direct seeding, we place the seed cost at $\$ 0.85$ per thousand white spruce seeds. Application by plane will be $\$ 20 /$ ha. We assume that a scarifying/seeding machine will scarify one-third of the area and thus use only $33 \%$ of the seeds used for aerial seeding.

We assume that for all prescriptions (except understory planting or the use of tall advance regeneration) dense aspen recruitment (augmented by a dense shrub component in the east) 
Table 4. Cost/scenario (\$/ha) for various conifer regeneration prescriptions with and without herbicides. Results are presented for full, moderate and minimal stocking. The block-wide contribution of advance regeneration $\left(T_{0}\right)$ to the total stocking is shown at three levels: $T_{0}=0, T_{0}=0.5 T_{s}$, and $T_{0}=T_{s}$ where $T_{s}$ is the block-wide stocking criterion. $F_{D A}$ is total reliance on the advance regeneration $\left(T_{0}=T_{s}\right)$; aerial refers to aerial seeding; $S S$ is use of a scarifer-seeding machine; mast year refers to reliance on a mast year following understory scarification (note that if $T_{0}=0$ then there is no advance regeneration and we assume therefore few or no source trees for this prescription); fill plant refers to the fill planting prescription (note that when $T_{0}=0$, there is no advance regeneration, the entire treated area is planted, and this is equivalent to a conventional plantation. Thus, $\$ 1100$ is the convention against which all other prescriptions can be compared

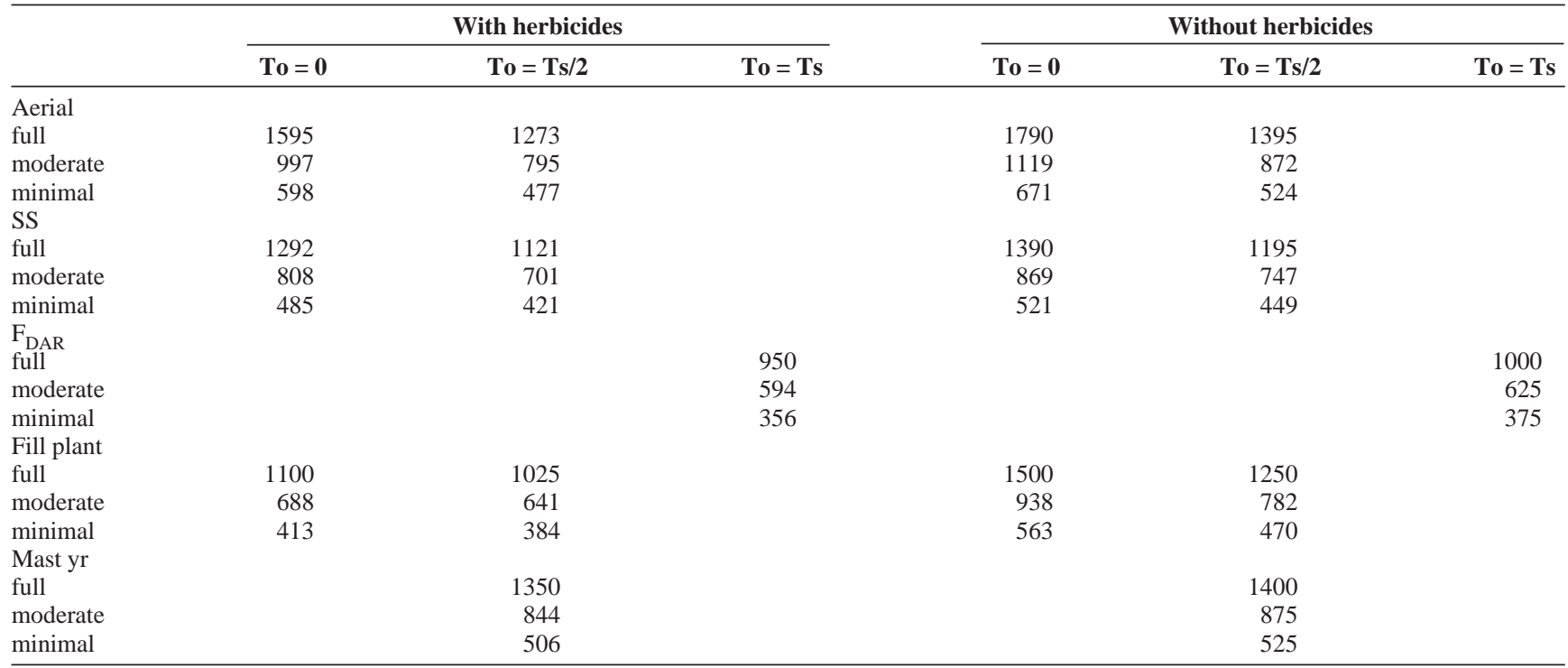

will overtop the short conifer regeneration. Thus, weeding will be required for subsequent conifer dominance. Herbicides (prohibited in Quebec after 2001) will cost \$200/ha. Mechanical weeding is much more expensive: $\$ 600 /$ ha. Precommercial thinning costs $\$ 750 /$ ha. However, for the portions of the block relying on non-planting prescriptions, the weeding and thinning treatments can be performed simultaneously at a total cost of $\$ 1000 /$ ha.

\section{Scenario costs}

The costs/ha outlined above are for a fully stocked stand but they need only be applied to the portion of the harvest block where we must intervene. The scenario cost is defined as the cost/ha for a prescription multiplied by the proportion of the harvest block to which it is applied.

Given the clumping of the advance regeneration at the scale of the harvest block, let us dichotomize it as two fractions, $\mathrm{h}$ and $\mathrm{g}$, where $\mathrm{h}$ has abundant regeneration and $\mathrm{g}$ has relatively little. Then, the observed block-wide stocking $\left(\mathrm{T}_{\mathrm{o}}\right)$ is

[7] $\mathrm{T}_{\mathrm{o}}=\mathrm{hT}_{\mathrm{h}}+\mathrm{gT} \mathrm{g}$

where $T_{h}$ is the local stocking in the fraction $h$ and $T_{g}$ is the local stocking in $\mathrm{g}$. For simplicity let us assume that our block-wide stocking standard $\left(\mathrm{T}_{\mathrm{s}}\right)$ requires that we augment $\mathrm{T}_{\mathrm{h}}$ by applying a full stocking standard $\left(\mathrm{T}_{\mathrm{F}}\right)$ to a part of $\mathrm{g}$ which we will call G. Then,

[8] $\mathrm{T}_{\mathrm{s}}=\mathrm{hT}_{\mathrm{h}}+(\mathrm{g}-\mathrm{G}) \mathrm{T}_{\mathrm{g}}+\mathrm{GT}_{\mathrm{F}}$

Equation (8) cannot be solved (as we have two unknowns) unless we make the following assumption: all the advance regeneration is found in the fraction $h$. If so, equation (8) becomes
[9] $\mathrm{T}_{\mathrm{s}}=\mathrm{To}+\mathrm{GT}_{\mathrm{F}}$

and we can now solve for $\mathrm{G}$, the fraction of the block where we must apply the prescription to achieve a block-wide stocking of $\mathrm{T}_{\mathrm{s}}$. Computer simulations indicate that the calculated $\mathrm{T}_{\mathrm{s}}$ in equation (9) will be within $5 \%$ of the calculated $\mathrm{T}_{\mathrm{s}}$ in equation (8) so long as $T_{h}>4 T_{g}$ at the block scale: i.e., the stems are quite clumped.

\section{Results of the cost/scenario analysis}

We now arrive at the comparison of scenario costs in a harvest block for each prescription based on the stocking derived from advance regeneration (which may of course be zero). Underplanting will be dealt with separately at the end of this section. In what follows it is assumed that there is always serious aspen competition except for underplanting (where sites have been judiciously chosen).

\section{Herbicides permitted}

When the advance regeneration is zero or very low, and full conifer stocking is required, the cheapest prescription is a conventional plantation (Table 4). Thus, the analysis confirms present practice. At lower stocking standards, fill planting becomes the cheapest alternative (merely the convention applied to a fraction of the block).

With a reasonable contribution from advance regeneration (as in Table 4: half the total required stocking), fill planting and use of a scarifier-sowing machine are roughly cost-equivalent prescriptions for moderate or minimal stocking criteria. Aerial seeding and reliance on a mast year are the most expensive alternatives.

When advance regeneration is adequate to meet the stocking standard, then reliance on these pre-existing stems is always the cheapest option. 
In summary, a conventional plantation is the cheapest option only if there is essentially no advance regeneration and full stocking is called for. Otherwise, fill planting is cheaper. As the amount of advance regeneration increases, the scarifier-seeder begins to approach fill planting as the method of choice.

\section{Herbicides prohibited}

While no other jurisdiction has followed the lead of Quebec, the banning of herbicides has a large effect on the comparative costs in Table 4. Not surprisingly, all costs rise as the weeding is now done by mechanical rather than chemical means, but the effect is especially pernicious for conventional plantations. All options except aerial seeding and reliance on a mast year are now cheaper than conventional clearcut/plantations no matter what the stocking criteria or contribution of advance regeneration density.

Where advance regeneration is sparse, the cheapest approach is now the scarifier-seeder. Fill planting is modestly more expensive, and mast year reliance and aerial seeding are the most expensive of the alternatives to conventional plantations.

Note that we have assumed the competition is primarily from shrubs and, especially, aspen. In the more open mixed stands of the west, bluejoint reed grass is often the most important competitor, and non-chemical control is typically ineffective. However, these are often the same stands that satisfy the light criterion for underplanting (Lieffers et al. 1993b).

\section{Underplanting}

With herbicides permitted, underplanting is essentially unaffected by the level of advance regeneration because the two prescriptions have similar total costs/ha. Reliance on advance regeneration for full stocking is $\$ 950 /$ scenario (Table 4) while underplanting costs $\$ 825 /$ scenario in the absence of any advance regeneration. Thus, relying on advance regeneration for any level of stocking makes little difference to the present cost. There would be, of course, a difference if interest costs, road maintenance or annual allowable cut (AAC) effects were taken into account. Note that the two prescriptions are fundamentally incomparable, as underplanting is limited to stands where light levels are very high. If advance regeneration existed in such stands, they would also be capable of becoming very tall, thus within a few decades obviating the weeding cost we have attached to reliance on advance regeneration.

\section{Conclusions}

The results of this modelling exercise of the joint effects of cost and biotic constraints on prescription choice must be regarded as tentative as there are a number of steps in the modelling that are unsupported by extensive data sets. With that caveat in mind, our main conclusions are as follows.

In the eastern mixedwood forest, the ubiquity of balsam fir advance regeneration and the opacity of the aspen crowns makes reliance on these pre-existing stems the most favourable prescription in the majority of stands. We think that underplanting is unlikely to be practised widely because too few blocks will meet the available light requirement. Where advance regeneration is present but insufficient to meet a stocking standard, the cheapest options for augmentation are fill planting and use of a scarifier-seeder. Aerial seeding and reliance on a mast year are always more costly than those two options.
The situation in the western mixedwood forests, where fir is much more rare than white spruce, is quite different. Very little of the landbase will have sufficient advance regeneration to meet even the minimal stocking standard. While much of this region has sufficient spruce basal area to permit reliance on a mast year, this prescription is never as cheap as the conventional clearcut/plantation (full stocking) or fill planting (moderate or minimal stocking). The cheapest prescription in the west is underplanting. However, if the Forest Management Area of Alberta Pacific is typical, only about $30 \%$ of the landbase is suitable.

Our analysis of biotic and cost constraints leads, essentially, to an endorsement of emerging contemporary practices in the southern boreal forest of Canada, especially those that use protection of advance regeneration to partially or fully stock mixedwood stands after logging. Our results, however, also show why industrial forestry has favoured clearcutting, planting and herbicides except where advance regeneration densities are very high. Underplanting approximately 20 years prior to logging appears to have considerable merit, especially in the west, if suitable access is available. This prescription is simply the artificial establishment of an advance regeneration component into mixedwood stands. We have demonstrated why aerial seeding of white spruce on boreal mixedwood sites has been so unsuccessful. The unreliability is due to too little seed and too little scarification. Increasing the reliability of aerial seeding is costly because of the enormous number of seeds per ha required to ensure a reasonable chance of success.

The prohibition of herbicides has a strong effect on the comparative costs of the prescriptions. Without herbicides, the high regeneration costs of plantations are now coupled with the higher tending costs (in this case mechanical weeding) normally associated with natural regeneration options. Whether other provinces will follow Quebec's example is not known.

We have found that the cheapest prescription depends on the stocking criteria. While full conifer stocking has been the management objective for many mixedwood sites in the past, there is considerable controversy regarding management goals for mixedwood forests across Canada. On public lands, the silvicultural objectives of forest owners or managers are frequently focused on achieving the current regeneration/stocking standards for a particular stand that has been cut. Most of the current standards were developed by regulators under the assumptions that a particular stand should be regenerated as a fully stocked, even-aged conifer monoculture despite the fact that aspen were present at the time of logging. The company that cuts a stand must by law achieve the regeneration performance dictated in the regulations. If a company wishes to cut more forest and maintain its allowable cut, it is critical that it achieves these standards on the areas it has already cut. However, as argued by Lieffers et al (1996a), mixedwood management might be better practised via moderate or minimal conifer stocking prescriptions. Further, a conversion to a conifer monoculture may not be desirable in terms of biodiversity issues. The analytical framework elaborated here forms the basis for determining when and how to implement a greater diversity of management prescriptions for mixed stands (i.e., minimal or moderate conifer stocking). Finally, remembering that we estimate only about $71 \%$ reliability for the full-stocking prescriptions entertained here, we think it is important that an organization be granted some flexibility with regard to composition and age structure at the stand scale; more inflexible standards should 
be reserved for the landscape scale (Kneeshaw et al. 2000). It will also, of course, be necessary to develop yield models for the mixed stands envisioned in some of these scenarios but this requirement is no different from any other management system one might entertain.

A related issue is the question of differing goals of various stakeholders. For example, in Québec and Alberta, current forest management agreements permit more than one company to hold cutting rights to the same landbase. Typically, one company may have rights to the hardwood component and another to the coniferous component. Clearly, the company that harvests aspen will not seriously entertain underplanting nor will the company permitted to harvest conifers have any incentive for reversion to aspen after the mature conifers are cut. This dichotomization of goals can lead to management practices with undesirable consequences (Cumming and Armstrong 2001). It is easy to turn a mixed stand into a virtual aspen monoculture over a few rotations as the conifer seed sources are removed (e.g., the dramatic reduction in white pine (Pinus strobus) stocks in eastern Canada over two centuries) while it is more costly to force the mixed stand toward a conifer monoculture under a regime of short rotations. Thus, the dichotomization would tend to produce more homogenous stands than the landscape has seen in the past, and it would not necessarily be (averaged across the landscape) the cheapest option. It appears that policy-makers and practitioners are growing increasingly aware of these risks (e.g., Lieffers and Beck 1994, MacDonald 1996), and are therefore more receptive to the objective of maintaining the multi-species composition of mixedwood stands and forests. Thus, managing the mixedwood as mixed stands at both stand and landscape scales would allow for a much richer variety of prescriptions. The quantitative framework presented here can serve as a palette for forest managers as they respond to the need to regenerate forests in a manner that is cost effective, conservative of landscape diversity, and more easily justified to environmentally-conscious consumers and voters.

\section{Acknowledgements}

Funding was provided by NCE-SFM, GREFi, NSERC, and ALPAC. Thanks are extended to all those who freely provided access to unpublished data. We would also like to thank two anonymous reviewers and The Forestry Chronicle Associate Editor for the incredible effort that they put into improving this manuscript.

\section{References}

Arnup, R.W. 1996. Stand and site conditions associated with the abundance and distribution of black spruce and balsam fir advance growth in northeastern Ontario. Nat. Resour. Can., Canadian Forest Service, Great Lakes Forestry Centre, Sault Ste. Marie, ON. NODA/NFP Tech. Rep. TR-29. 25 p.

Coates, K.D. 2000. Conifer seedling response to northern temperate forest gaps. For. Ecol. Manage. 127: 249-269.

Coates, K.D. and P.J. Burton. 1999. Growth of planted tree seedlings in response to ambient light levels in northwestern interior cedar-hemlock forests of British Columbia. Can, J. For. Res. 29: 1374-1382. Coates, K.D., S. Haeussler, S. Lindeburgh, R. Pojar and A.J. Stock. 1994. Ecology and silviculture of interior spruce in British Columbia. Can/B.C. Economic and Regional Devel., FRDA Rep. 220, Victoria, $\mathrm{BC}$.

Cumming, S.G. and G.W. Armstrong. 2001. Divided landbase and overlapping forest tenure in Alberta Canada: A simulation study exploring costs of forest policy. For. Chron. 77: 501-508.
D'Astous, M.-O. 2000. Caractérisation de la transmission de la lumière en forêt boréale: effets de la richesse, la composition et la structure d'un peuplement forestier. Masters Thesis, Université du Québec à Montréal, Montréal, Québec. 65 p.

DeLong, S.C. 1997. Operational consideration for underplanting hardwood stands with white spruce. B.C. Ministry of Forests, Forest Research Note PG-11, Prince George Forest Region.

DeLong, S.C., R.M. Sagar, D. Tanner, V. Sit and A. Eastham. (submitted.) Performance of white spruce seedlings in relation to microclimate under 40- to 80-year old aspen canopies and in clearcuts. Manuscript submitted to For. Ecol. and Manage.

Desjardins, M. 1988. White spruce natural seeding. In On Line to Northern Forest Developments. pp. 9-10. Ontario Ministry of Natural Resources, Toronto, Ontario.

Doucet, R. 1988. La régénération préétablie dans les peuplements forestiers naturel au Quebec. For. Chron. 64: 116-120.

Doucet, R. 1992. Québec's proposed forest protection strategy: Impact on regeneration options. In The silviculture conference: Stewardship in the new forest. Nov 18-20, 1991. Vancouver, B.C. pp. 113-119. Forestry Canada, Ottawa

Fleming, R.L., D.S. Mossa and T.R. Burns 1987. Scarification trials for direct seeding on upland black spruce sites in Northwestern Ontario. Can. For. Serv., Great Lakes For. Cent., Inf. Rep. 0-X-385. Fox, J.D., J.C. Zasada, A.F. Gasbarro and R. Van Veldhuizen. 1984. Monte Carlo simulation of white spruce regeneration after logging in interior Alaska. Can. J. For. Res 14: 617-622.

Frisque, G., G.F. Weetman and E. Clemmer. 1978. Analyse, 10 ans après coupe de bois à pâte, des problèmes de régénération dans l'est du Canada. Forest Engineering Research Institute, PointeClaire, Quebec, Tech. Rep. TR-23.

Greene, D.F. and E.A. Johnson. 1996. Wind dispersal of seeds from a forest into a clearing. Ecology 77: 595-609.

Greene, D. F. and E.A. Johnson. 1998. Seed mass and early survivorship of tree species in upland clearings and shelterwoods. Can. J. For. Res. 28: 1307-1316.

Greene, D.F., J.C. Zasada, L. Sirois, D. Kneeshaw, H. Morin, I. Charron and M.-J. Simard. 1999. A review of the regeneration of boreal forest trees. Can. J. For. Res. 29: 824-839.

Greene, D.F., C. Messier, H. Asselin and M.J. Fortin. 2002. Predicting cone production in understory fir and white spruce. Can. J. Bot. (In Press).

Griffin, R.H. and B.W. Carr. 1973. Aerial seeding of spruce in Maine. In Cayford, J.H. (ed.). Direct seeding symposium. pp. 131-138. Canada Dept. Environment, Can. For. Serv., Ottawa, Publ. No 1339.

Groot, A. 1999. Effects of shelter and competition on the early growth of planted white spruce (Picea glauca). Can. J. For. Res. 29: 1002-1014. Harvey, B.D. and Y. Bergeron. 1989. Site patterns of natural regeneration following clear-cutting in northwestern Quebec. Can. J. For. Res. 19: 1458-1469.

Jarvis, J.M. 1966. Project Ms-228: shelterwood cutting and mechanical seedbed treatment in white spruce-trembling aspen stands to induce white spruce regeneration, Manitoba and Saskatchewan. In Jarvis, J.M., G.A Steneker, R.M. Waldron and J.C. Lees (eds.). Review of silvicultural research of white and trembling aspen cover types, mixedwood forest section, boreal forest region, Alberta-SaskatchewanManitoba. Can. For. Serv., Forestry Branch, Ottawa, Publ. No 1156. $183 \mathrm{p}$.

Johnson, H.J. 1986. The release of white spruce from trembling aspen overstoreys. A review of available information and silvicultural guideline. Manitoba Dept. Nat. Res., Forestry Branch. Winnipeg. $109 \mathrm{p}$.

Kneeshaw, D.D. and Y. Bergeron. 1998. Canopy gap characteristics and tree replacement in the southeastern boreal forest. Ecology 79: 783-794.

Kneeshaw, D.D., Y. Bergeron and L. DeGrandpré. 1998. Early seedling response of Abies balsamea to artificially created openings. J. Veg. Sci. 9: 543-550. 
Kneeshaw, D.D., A. Leduc, C. Messier, P. Drapeau, D. Paré, S. Gauthier, R. Carignan, R. Doucet and L. Bouthillier. 2000. Developing biophysical indicators of sustainable forest management at an operational scale. For. Chron. 76: 482-493.

Kneeshaw, D.D., H. Williams, E. Nikinmaa and C. Messier. 2002. Above and below ground response of two understory coniferous species six years after selection cutting. Can. J. For. Res. (In Press) Kobe, R.K. and K.D. Coates. 1997. Models of sapling mortality as a function of growth to characterize interspecific variation in shade tolerance of eight tree species of northwestern British Columbia. Can. J. For. Res. 27: 227-236.

Lees, J.C. 1963. Partial cutting and scarification in Alberta spruceaspen forests. Canada Dept. For., For. Res. Branch, Ottawa, Ontario, Publ. No. 1001.

Lees, J.C. 1970. Partial cutting and scarification of white spruce under spruce-aspen shelterwood, B-18a forest section, Alberta. Dept Fish For., Can. For. Serv., Ottawa, Ontario, Publ No. 1274

Lieffers, V.J. and J.A. Beck Jr. 1994. A semi-natural approach to mixedwood management in the prairie provinces. For. Chron. 70: 260-264. Lieffers, V.J. and K.J. Stadt. 1994. Growth of understory Picea glauca, Calamagrostis canadensis, and Epilobium angustifolium in relation to overstory light. Can. J. For. Res. 24: 1193-1198.

Lieffers, V.J., A.G. Mugasha.and S.E. Macdonald. 1993a. Ecophysiology of shade needles of Picea glauca saplings in relation to removal of competing hardwoods and degrees of prior shading. Tree Physiology 12: 271-280.

Lieffers, V.J., S.E. Macdonald and E.H. Hogg. 1993b. Ecology of and control strategies for Calamagrostis canadensis in boreal forest sites. Can. J. For. Res. 23: 2070-2077.

Lieffers, V.J., R.B. Macmillan, D. MacPherson, K. Branter and J.D. Stewart. 1996a. Semi-natural and intensive silvicultural systems for the boreal mixedwood forest. For. Chron. 72: 286-292.

Lieffers, V.J., K.J. Stadt and S. Navratil. 1996b. Age structure and growth of understory white spruce under aspen. Can. J. For. Res. 26: 1002-1007.

Lieffers, V.J., C. Messier, F. Gendron, P. Comeau and K.J. Stadt. 1999. Prediction and managing light in the understory of boreal forests. Can. J. For. Res. 29: 796-811.

MacDonald, G.B. 1996. The emergence of boreal mixedwood management in Ontario: background and prospects. In Smith, C.R. and G.W. Crook (eds.). Advancing Boreal Mixedwood Management in Ontario: Proceedings of a Workshop. Oct. 17-19, 1995, Sault Ste. Marie, Ontario. pp.11-20. Can. Dept. Nat. Res., Can. For. Serv. (Sault Ste. Marie), and Ont. Min. Nat. Res., Sault Ste Marie. 239 p.

MacDonnell, M.R. and A. Groot. 1997. Harvesting peatland black spruce: impacts on advance growth and site disturbance. For. Chron. 73: 249-255.

McCaughey, W.W. and D.E. Ferguson. 1988. Response of advance regeneration to release in the inland mountain west: a summary. In Schmidt, W.C. (ed.). Future forests of the Mountain West: A stand culture symposium. Proceedings. pp. 255-266. USDA For. Serv. Gen. Tech. Rep. INT 243.

McInnis, B.G. and M.R. Roberts. 1994. The effects of full-tree and tree-length harvests on natural regeneration. North. J. Applied For. 11: 131-137.

Man, R. and V.J. Lieffers. 1999. Effects of shelterwood and site preparation on climate and establishment of white spruce seedlings in a boreal mixedwood forest. For. Chron.75: 837-844.

Messier, C., S. Parent and Y. Bergeron. 1998. Characterization of understory light environment in closed mixed boreal forests: effects of overstory and understory vegetation. J. Veg. Sci. 9: 511-520.

Messier, C., R. Doucet, J.-C. Ruel, Y. Claveau, C. Kelly and M. Lechowicz. 1999. Functional ecology of advance regeneration growth and survival up to pole-size in coniferous boreal forests. Can. J. For. Res. 29: 812-823.

Murphy, T.E.L., D.L. Adams and D.E. Ferguson. 1999. Response of advance lodgepole pine regeneration to overstory removal in eastern Idaho. For. Ecol. Manage. 120: 235-244.
Navratil, S., L.G. Brace, E.A. Sauder and S. Lux. 1994. Silvicultural and harvesting options to favor immature white spruce and aspen regeneration in boreal mixedwoods. Can. For. Serv., North. For. Centre, Inf. Rep. NOR-X-327, Edmonton, Alberta.

Peterson, E.B. and N.M. Peterson. 1992. Ecology, management, and use of aspen and balsam popular in the prairie provinces. Forestry Canada, Northern Forestry Centre, Special Report No. 1. Pike, R.T. and R.M. Waldron. 1966. Project MS-166: Cutting methods for management of white spruce, Riding Mountain. In Jarvis, J.M., G.A. Steneker, R.M. Waldron and J.C. Lees. (eds.). Review of silvicultural research, white spruce and trembling aspen cover types in the mixedwood forest section of the boreal forest region of Alberta-Saskatchewan-Manitoba. pp. 151-152. Can. For. Serv., Forestry Branch, Publ. No 1156. Ottawa, Ontario.

Pinno, B.D. 2000. Crown characteristics and understory light in young trembling aspen stands. M.Sc. Thesis, University of Alberta, Edmonton, Alberta.

Radvanyi, A. 1987. Snowshoe hares and forest plantations: a literature review and problem analysis. Can. For. Serv., North. For. Cen., Edmonton, Alberta. Inf. Rep. NOR-X-290.

Randall, A.G. 1974. Seed dispersal into two spruce-fir clear-cuts in eastern Maine. Research in the Life Sciences 21: 1-15.

Raymond, P. 1998. Efficacité du système de régénération par coupes progressives dans les sapinières boréales riches: résultats cinq ans après la coupe d'ensemencement. Mémoire de maîtrise, Faculté de Foresterie et de Géomatique Université Laval, Québec.

Roberts, M.R. and H. Dong. 1993. Effects of soil organic layer removal on regeneration after clearcutting a northern hardwood stand in New Brunswick. Can. J. For. Res. 23: 2093-2100.

Rowe, J. S. 1992. The ecosystem approach to forestland management. For. Chron. 68: 222-224.

Ruel, J.-C., R. Doucet and J. Boily. 1995. Mortality of balsam fir and black spruce advance growth 3 years after clearcutting. Can. J. For. Res. 25: 1528-1537.

Ruel, J.-C., C. Messier, R. Doucet, Y. Claveau and P. Comeau. 2000. Review of possible individual or combined morphological indicators to assess the vigour of regenerating trees in natural conditions. For. Chron. 76: 633-642.

Stewart, J.D., E.H. Hogg, P.A. Hurdle, K.J. Stadt, P. Tollestrup and V.J. Lieffers. 1998. Dispersal of white spruce in mature aspen stands. Can. J. Bot. 76: 181-188.

Stewart, J.D., S.M. Landhausser, K.J. Stadt and V.J. Lieffers. 2000. Regeneration of white spruce under aspen canopies: seeding, planting and site preparation. Western J. Appl. For. 15: 177-182.

Su, Q., D.A. MacLean and T.D. Needham. 1996. The influence of hardwood content on balsam fir defoliation by spruce budworm. Can. J. For. Res. 26: 1620-1628.

Tanner, D., S.C. DeLong and A. Eastham. 1996. Investigations of planting white spruce under a trembling aspen canopy. In Comeau, P.G. and K.D. Thomas (eds.). Silviculture of Temperate and Boreal Broadleaf-conifer mixtures. pp. 114-121. B.C. Min. of Forests, Research Branch, IV Series. Victoria, B.C.

Taylor, S.P., R.I. Alfaro, C. DeLong and L. Rankin. 1996. The effects of overstory shading on white pine weevil damage to white spruce and its effects on spruce growth rates. Can. J. For. Res. 26: 306-312. Timoney, K.P. and G. Peterson. 1996. Failure of natural regeneration after clearcut logging in Wood Buffalo National Park, Canada. For. Ecol. Manage. 87: 89-105.

Waldron, R. M. 1974. Direct seeding in Canada 1900-1972. In Cayford, J.H. (ed.). Direct seeding symposium. pp. 11-27. Environment Canada, For. Serv., Ottawa, Publ. No. 1339.

Weiner, J. and S.C Thomas. 1986. Size variation in plant monocultures. Oikos 47: 211-222.

Wright, E.F., K.D. Coates and P. Bartemucci. 1998a. Regeneration from seed of 6 tree species in the interior cedar-hemlock forests of British Columbia as affected by substrate and canopy gap position. Can. J. For. Res. 28: 1352-1364. 
Wright, E.F., K.D. Coates, C.D. Canham and P. Bartemucci. 1998b. Species variability in growth response to light across climatic regions in northwestern British Columbia. Can J. For. Res. 28: 871-876.

Wright, E.F., C.D. Canham and K.D. Coates. 2000. Effects of suppression and release on sapling growth for eleven tree species of northern, interior British Columbia. Can. J. For. Res. 30: 1571-1580.

Yang, R. C. 1989. Growth response of white spruce to release from trembling aspen. Can. For. Serv., North. For. Cent., Edmonton, Inf. Rep. NOR-X-302.
Zelasny, V. and M. Hayter. 1991. Predicting natural regeneration abundance with a productivity-oriented site classification. In C.M. Simpson (ed.). Proceedings of the Conference on Natural Regeneration Management. March, 1990, Fredericton, New Brunswick. pp. $25-41$. 